\title{
The influence of second language vowels on foreign language vowel perception
}

\author{
Anna Balas*1
}

\begin{abstract}
This paper examines the limits of feature abstraction and the influence of second language vowels on foreign vowel perception (cf. Pajak and Levy 2014). Perception of Dutch vowels by Polish students of English and French and Dutch was assessed using categorization tasks with goodness ratings. Dutch front rounded vowels were identified predominantly as front vowels by learners of French and Dutch and as back vowels by learners of English. The results suggest that the hypothesis about selective attention to features should incorporate markedness and that experience with second language front rounded vowels is enough to trigger disentangling rounding from backness.
\end{abstract}

Keywords. foreign vowel perception, selective attention to features, front rounded vowels.

1. Introduction. Pajak and Levy (2014) postulate an important role for selective attention to features in second language speech perception. They argue that listeners have enhanced sensitivity along phonetic dimensions that their L1 uses to distinguish between phonetic categories. For example, lip rounding as a vowel feature in L1 raises sensitivity to liprounding contrasts in approximants /w-j/ (Bohn and Best 2012, Hallé et al. 1999).

This paper examines the limits of feature abstraction and the influence of second language vowels on foreign vowel perception. Does familiarity with L1 Polish back rounded vowels allow for perception of front rounded vowels of various heights? It is furthermore tested whether subjects have different perceptual sensitivity depending on their L2.

2. Method. The case examined is perception of Dutch vowels by Polish students of English and French in comparison with a control group of Polish students of Dutch. The purpose is to examine how the feature +rounded interacts with other features such as height and backness. The subjects were three groups of native Polish students of: English, French and Dutch. They were all second language learners, instead of L1 speakers of respective languages, so that a common L1 with no rounded vowels could serve as tertium comparationis. The second languages were chosen to have larger vowel inventories than Polish with (French and Dutch) and without (English) front rounded vowels. The tested language was Dutch.

2.1. SuBJECTS. The subjects were Polish advanced students of English, French and Dutch, majoring in respective languages at university. The subjects completed pronunciation courses in their respective L2s. There were 26 students of English, 12 students of French and 9 students of Dutch. All subjects in this experiment were advanced -level learners of English, in addition to being advanced learners of a language they majored in. In fact, the term "L2"

\footnotetext{
${ }^{1}$ This research was supported by grant no. UMO-2015/17/B/HS2/01246 "Perceptual reorganization of speech: the interplay of categories and features" from the National Science Centre, Poland. I would also like to thank Katarzyna Dziubalska-Kołaczyk, Magdalena Wrembel and Jarosław Weckwerth for their advice on matters discussed in the present paper. Author: Anna Balas, Faculty of English, Adam Mickiewicz University in Poznań, Poland (abalas@wa.amu.edu.pl).
} 
used here, must be treated with caution, as all of the subjects started learning English as their L2 before they were 10 years old, but students of Dutch and French became more proficient and at the time of the experiment they had more practice in the languages they majored in.

2.2. PROCEDURE. The experiment consisted of an identification test with category goodness ranking of Dutch vowels in terms of Polish vowels. The subjects performed a keyword identification of the 8 Dutch vowels / i, I, u, ø, y, Y/ (and two more vowels not reported here) in terms of six Polish vowel categories $/ \mathrm{i}$ i $\varepsilon$ a o $\mathrm{u} /$. The labels in the experiment were orthographical: $i, y, e, a, o$ and $u$, since Polish vowel orthography is transparent. The tested items were eight vowel categories, 2 tokens per category, and three repetitions per token, which yields 48 trials. They were presented randomly, and they were preceded by warm-up items. On a given trial the subjects listened to a single token played twice. After the first presentation they clicked on a Polish keyword corresponding to the vowel that they heard in the item. Then the subjects rated the similarity of the vowel in the auditory stimulus to the vowel in the chosen keyword ( 1 being barely similar and 5 being a very good fit).

3. Results. Identification patterns consistently varied between language groups. Experience with L2 front rounded vowels exerted influence on Dutch as a foreign language vowel perception. Dutch /y y/ and /ø / were identified predominantly as front vowels by learners of L2 with front rounded vowels (for example, Dutch /y/ was categorized as Polish /i/ by $77 \%$ of Dutch learners, $69 \%$ of French learners and only by $43 \%$ of English learners) and as back vowels by learners lacking experience with the feature + rounded used with front vowels. Dutch $/ \mathrm{u} /$ was interpreted as $/ \mathrm{u} /$ across the board.

\begin{tabular}{|c|c|c|c|c|c|c|c|}
\hline \multirow{2}{*}{$\begin{array}{l}\text { Dutch } \\
\text { stimuli }\end{array}$} & \multirow{2}{*}{$\begin{array}{l}\text { Polish } \\
\text { learners of: }\end{array}$} & \multicolumn{6}{|c|}{ Targets: Polish vowel categories } \\
\hline & & $\mathrm{i}$ & $\mathrm{y}$ & e & $\mathrm{a}$ & $\mathrm{o}$ & $\mathrm{u}$ \\
\hline \multirow[t]{3}{*}{ /i:/ } & English & $\begin{array}{l}99.4 \\
(3.7)\end{array}$ & & & & & $\begin{array}{l}0.6 \\
(1)\end{array}$ \\
\hline & French & $\begin{array}{l}100 \\
(4.8)\end{array}$ & & & & & \\
\hline & Dutch & $\begin{array}{l}98.1 \\
(4.4)\end{array}$ & & & & & $\begin{array}{l}1.9 \\
(1)\end{array}$ \\
\hline \multirow[t]{3}{*}{$/ \mathrm{I} /$} & English & $\begin{array}{l}30.4 \\
(3.4)\end{array}$ & $\begin{array}{c}69 \\
(3.6)\end{array}$ & & & & $\begin{array}{l}0.6 \\
(1)\end{array}$ \\
\hline & French & $\begin{array}{c}5.6 \\
(3.2)\end{array}$ & $\begin{array}{l}58.3 \\
(3.3)\end{array}$ & $\begin{array}{l}36.1 \\
(3.8)\end{array}$ & & & \\
\hline & Dutch & $\begin{array}{c}50 \\
(3.5)\end{array}$ & $\begin{array}{c}50 \\
(3.7)\end{array}$ & & & & \\
\hline \multirow[t]{2}{*}{$\mid \mathrm{y} /$} & English & & $\begin{array}{l}45.5 \\
(3.2)\end{array}$ & $\begin{array}{l}3.6 \\
(3)\end{array}$ & & & $\begin{array}{l}51.95 \\
(2.9)\end{array}$ \\
\hline & French & & $\begin{array}{l}69.4 \\
(3.2)\end{array}$ & $\begin{array}{l}5.6 \\
(2)\end{array}$ & & $\begin{array}{c}8.4 \\
(1.3)\end{array}$ & $\begin{array}{l}16.7 \\
(3.3)\end{array}$ \\
\hline
\end{tabular}




\begin{tabular}{|c|c|c|c|c|c|c|}
\hline & Dutch & & $\begin{array}{l}77.8 \\
(3.6)\end{array}$ & & & $\begin{array}{l}22.22 \\
(4.5)\end{array}$ \\
\hline \multirow[t]{3}{*}{$/ \mathrm{Y} /$} & English & $\begin{array}{c}2.54 \\
(2)\end{array}$ & $\begin{array}{c}28.81 \\
(3)\end{array}$ & $\begin{array}{c}1.69 \\
(2)\end{array}$ & & $\begin{array}{c}66.95 \\
(3)\end{array}$ \\
\hline & French & $\begin{array}{c}7.41 \\
(1.75)\end{array}$ & $\begin{array}{l}48.2 \\
(3.1)\end{array}$ & $\begin{array}{c}2.78 \\
(2)\end{array}$ & $\begin{array}{l}0.9 \\
(2)\end{array}$ & $\begin{array}{c}40.74 \\
(3)\end{array}$ \\
\hline & Dutch & $\begin{array}{l}3.7 \\
(2)\end{array}$ & $\begin{array}{c}51.85 \\
(3)\end{array}$ & & & $\begin{array}{l}44.44 \\
(3.1)\end{array}$ \\
\hline \multirow[t]{3}{*}{$\mid \varnothing /$} & English & $\begin{array}{l}0.6 \\
(2)\end{array}$ & $\begin{array}{l}18.5 \\
(2.3)\end{array}$ & $\begin{array}{c}12 \\
(2.1)\end{array}$ & $\begin{array}{l}0.6 \\
(1)\end{array}$ & $\begin{array}{l}68.2 \\
(2.6)\end{array}$ \\
\hline & French & & $\begin{array}{l}51.4 \\
(2.9)\end{array}$ & $\begin{array}{c}12.5 \\
(2)\end{array}$ & $\begin{array}{l}15.3 \\
(1.2)\end{array}$ & $\begin{array}{l}20.8 \\
(2.2)\end{array}$ \\
\hline & Dutch & & $\begin{array}{l}46.3 \\
(2.8)\end{array}$ & $\begin{array}{c}3.7 \\
(1.5)\end{array}$ & & $\begin{array}{c}50 \\
(2.3)\end{array}$ \\
\hline \multirow[t]{3}{*}{$/ \mathrm{u} /$} & English & & & & & $\begin{array}{c}100 \\
(3.3)\end{array}$ \\
\hline & French & & $\begin{array}{l}0.4 \\
(4)\end{array}$ & & & $\begin{array}{l}98.6 \\
(4.2)\end{array}$ \\
\hline & Dutch & & & & & $\begin{array}{c}100 \\
(3.9)\end{array}$ \\
\hline
\end{tabular}

Table 1: Mean per cent categorization and goodness rating (in parentheses) of Dutch vowels in terms of Polish vowel categories / a e i o u $\dot{\mathrm{i}}$ / by Polish learners of English, Dutch and French . The goodness ratings are based on a scale that ranged from 1 (barely similar) to 5 (identical).

4. Discussion. This section discusses categorization results of Dutch vowels in terms of Polish vowel labels.

The Dutch vowel/i:/ is perceived as /i/ by over $98 \%$ of subjects, even though it's tenser than the Polish counterpart - this might explain why the goodness ratings are only moderately high. There is a discrepancy between how well-fit the subjects perceive the Dutch /i:/ to be in terms of the Polish /i/: English (3.7), Dutch (4.4) and French (4.8). Perhaps the learners of French, not acquainted with length differences, do not pay attention to the longer duration of the vowel in comparison to the Polish standard.

The Dutch /I/ is perceived as /i:/ by $30.4 \%$ of English learners, $50 \%$ of Dutch learners and only $5.6 \%$ of French learners, as $/ \mathrm{I} /$ by $69 \%$ of English learners, $50 \%$ of Dutch learners and $58 \%$ of French learners. Perception and production of $/ \mathrm{I} /$ is a notorious problem for Polish learners of English because of orthography (cf. Bogacka [Balas] 2004). The letter $i$ which denotes /I/ in Germanic languages is always read in Polish as /i/. This explanation of course assumes that spelling pronunciation is transferred onto perception. Noteworthy, $36.1 \%$ of French learners perceive /I/ as /e/. This might stem from the fact that French /e/ is higher 
than in other languages. The goodness ratings of /I/ are around 3.5, which denotes a fairly good match of the Dutch /I/ and the chosen Polish categories.

Dutch $/ \mathrm{y} /$ is a front rounded vowel, which is perceived as $/ \mathrm{u} /$ or $/ \mathbf{i} /$ by learners of English who are not familiar with front rounded vowels and predominantly as /ít by learners of Dutch and French who are accustomed to front rounded vowels. Goodness ratings here vary, but noteworthy learners of Dutch give higher goodness ratings than the remaining two groups, which might stem from the fact that the tested language is their L2, and not a foreign language, i.e. they are more familiar with the vowels presented.

The results for $/ \mathrm{y} /$ are similar to the results for $/ \mathrm{y} /$-- there is even slightly more balance between $/ \mathrm{u} /$ and $/ \mathbf{i} /$ categorizations by learners of Dutch and French, probably because $/ \mathrm{y} /$ is more centralized than $/ \mathrm{y} /$. For the same reason learners of English increasingly chose the $/ \mathrm{u} /$ as a target.

When Polish learners heard the Dutch /ø/, the winning target was /u/ for English and Dutch speakers, but French learners preferred /it/. The vowel /i/ was also a common second choice for other learners. Goodness ratings are really low, probably because this Dutch vowel is a front centralized rounded vowel, so it is different from a back rounded $/ \mathrm{u} /$ and different from a front unrounded $/ \mathbf{i} /$. Dutch and French learners gave higher goodness ratings to $/ \mathbf{i} /$ than to $/ \mathrm{u} /$ probably because they had been used to hearing non-back vowels being rounded.

Dutch $/ \mathrm{u} /$ is categorized as Polish / $\mathrm{u} /$, with mean goodness ratings varying between 3.3 for English learners and 4.2 for learners of French. This result is important as a reference point for discussing categorization of front rounded vowels.

5. Conlusions. The above results provide evidence that L2 influences foreign vowel perception, ie. evidence for language-specific L2 influence on foreign language vowel perception. Identification patterns for front and central rounded vowels consistently vary across L2 groups. This means that experience with L2 categories and L1 features used in new combinations in L2 (e.g. here front rounded vowels, where the feature [+rounded] is used in a new context for native Polish listeners) exerts influence on foreign language vowel perception. This finding is important for the initial stage (Rothman 2011) perception in L3 acquisition.

Furthermore, with regard to selective attention to features (Pajak and Levy 2014), these results suggest that familiarity with the feature [+rounded] from L1 (Polish uses rounding for its back vowels and $/ \mathrm{w} /$, but the feature is not used contrastively/distinctively) does not mean it can be easily abstracted and used in a completely different context (front vowels). It is therefore argued that the hypothesis about selective attention to features should incorporate markedness - i.e. you do not re-use the feature known from L1, if it means opting for a marked combination of features (front rounded vowels are marked, less-frequent in world languages. The other explanation for the lack of selective attention to features known from L1 in a foreign language would be that the feature in question must be contrastive in L1.This claim would be in line with Bohn and Best's (2012) finding where native German listeners, who do not have $/ \mathrm{w} /$ in their L1 inventory, discriminated the $/ \mathrm{w} /-\mathrm{j} /$ contrast better than native English listeners. The authors attribute the enhanced sensitivity to $/ \mathrm{w} /-\mathrm{j} / \mathrm{contrast}$ to both the vowel-like properties of word-initial approximants and experience with contrastive lip rounding for front vowels.

The present results suggest that the two features [+rounded] and [+back] are linked in Polish in an implicational hierarchy, in which [+rounded] implies [+back]. As an L1 Polish listener you need experience with front unrounded and rounded vowels in your L2, i.e. with an active feature, to trigger disentangling rounding from backness. 


\section{References}

Bogacka [Balas], Anna. 2004. On the perception of English high vowels by Polish learners of English. In E. Daskalaki; N. Katsos; M. Mavrogiorgos; M. Reeve (eds.) CamLing 2004: Proceedings of theUniversity of Cambridge Second Postgraduate Conference in Language Research. Cambridge: Cambridge Institute of Language Research. 43-50.

Bohn, Ocke-Schwen \& Catherine Best. 2012. Native-language phonetic and phonological influences on perception of American English approximant by Danish and German listeners. Journal of Phonetics 40 (1). 109-128. https://doi.org/10.1016/j.wocn.2011.08.002.

Hallé, Pierre, Catherine T. Best \& Andrea Levitt.1999. Phonetic vs. phonological influences on French listeners perception of American English approximants. Journal of Phonetics 27 (3). 281-306. https://doi.org/10.1006/jpho.1999.0097.

Pajak, Bozena \& Roger Levy. 2014. The role of abstraction in non-native speech perception. Journal of Phonetics 46. 147-160. https://doi.org/10.1016/j.wocn.2014.07.001.

Rothman, Jason. 2011. L3 syntactic transfer selectivity and typological determinacy: The typological primacy model. Second Language Research 27 (1). 107-127. https://doi.org/10.1177/0267658310386439. 